\title{
Nutritive Value of Forages on Sandy Soils as Affected by Tebuthiuron
}

\author{
MARIO BIONDINI, R.D. PETTIT, AND VIRGIL JONES
}

\section{Abstract}

Tebuthiuron, [N-(5-1,1-dimethyethyl-11,3,4thiadiazol-2-yl)-N,N'dimethylurea, a root-absorbed pelleted herbicide, was broadcast onto sand shinnery oak (Quercus havardii) rangeland in west Texas, May 1978. Green herbage of the dominant grasses was assayed for nitrogen (N), phosphorus (P), 24-hr in vitro dry matter digestibility ( $24 \mathrm{hr}$-IVDMD), and cell wall content (CWC) on 3 dates in both 1978 and 1979.

In 1978, tebuthiuron at $0.4 \mathrm{~kg} / \mathrm{ha}$ or above improved quality of the major forages. Crude protein was up to $28 \%$ higher in treated plants the year of application. The $P$ content ranged from 0.08 to $0.12 \%$ over all sampling dates. Digestibility inereased slightly while no difference was found in CWC. Tebuthiuron had no effect on forage quality the year after application.

The most consistent change in parameters measured was water content of little bluestem (Schizachyrium scoparium). Untreated plants averaged $38 \%$ water throughout the growing season, while treated plants contained $50 \%$ water. Major benefits of killing oak are increased forage availability and not yet resolved palatability factors.

Over 2 million ha of sandy soils in the Southern Great Plains support sand shinnery oak (Quercus havardii). This dwarf oak provides some food and cover for livestock and wild life, but its new growth is toxic to domestic stock. Nearly $80 \%$ of the standing crop is oak. Conversion of this shrub type to a mid-grass prairie is a goal of many ranchers. In December, 1979, tebuthiuron was registered for use on this species. Pettit (1979) found that some oak may be controlled with tebuthiuron at rates as low as $0.24 \mathrm{~kg} / \mathrm{ha}$. Concomitant to increased production, forage quality may be improved with herbicides (Bovey et al. 1972, Scifres et al. 1977).

Cattle seem to prefer grazing forages treated with tebuthiuron. This preference may be related to forage quality. Arnold (1964) found grazing animals to prefer forages high in nitrogen $(\mathrm{N})$, phosphorus (P), and sugar, but low in fiber. Leigh (1961) stated that forage water content was highly correlated to preference.

Herbicidal effects on the nutritive content of rangeland forages are not fully understood. The study by Houston and Van Sluijs (1975) is not directly applicable to our area because of soil fertility and environmental differences. Sosebee (1979) used high rates of tebuthiuron $(9 \mathrm{~kg} / \mathrm{ha})$ and found that forage protein, $P$, and carotene were not affected, but forage water content was increased. The impacts of herbicides on digestibility and cell wall content (CWC) of forages after herbicide treatment have not been reported for sandyland forages.

\section{Methods and Procedures}

\section{Study Area}

Test plots were in Cochran County, Texas, $25 \mathrm{~km}$ north and 4.5 $\mathrm{km}$ east of Plains, Texas. Unt reated communities are dominated by oak with little bluestem (Schizachyrium scoparium) and purple threeawn (Aristida purpurea) dominating. These plus sand dropseed (Sporobolus cryptandrus) red lovegrass (Eragrostis secundiflora), and hairy grama (Bouteloua hirsuta) constitute nearly $90 \%$ of the grass biomass. Forbs are common but typically yield less than $50 \mathrm{~kg} / \mathrm{ha}$.

\footnotetext{
Authors are former graduate research assistant, associate professor, and graduate research assistant, Department of Range and Wildlife Management, Texas Tech University, Lubbock 79409. Biondini's present address is Department of Animal and Range Sciences, North Dakota State University, Fargo, ND 58103.

This is Texas Tech University College of Agricultural Sciences Publication No. T-9-247.

Manuscript accepted 13 January 1986.
}

Topography of the study area was relatively flat. Of the 4 soils in the area, 3 were Alfisols (Paleustalfs) and the small area of dunes was an Entisol (Ustipsamment). Soil surface horizons were from 92 to $95 \%$ sand. The subsoil, usually sandy clay loam, restricts water movement through the profile. Water availability is high when soils are wet. Soil fertility is low.

The climate is warm, temperate and continental. Air temperatures range from 44 to $-25^{\circ} \mathrm{C}$. The first freeze is near 1 November and the last is around 1 April. After frost oak leaves are dropped. Precipitation averages $40 \mathrm{~cm} / \mathrm{yr}$ with up to $80 \%$ received in the growing season.

A completely randomized design with 3 replications of $0.0,0.2$, $0.4,0.6,0.8$, and $1.0 \mathrm{~kg} \mathrm{a.i./ha}$ of tebuthiuron was used. The herbicide was broadcast 10 May 1978 onto 2-ha plots with a motorized Cyclone seeder attached $2.5 \mathrm{~m}$ above ground behind a tractor.

\section{Sampling Procedures}

All herbage in $10,0.5-\mathrm{m}^{2}$ randomly placed quadrats was clipped at a $1-\mathrm{cm}$ stubble height in each of the 18 plots. Samples were collected $40,67,108,349,412$, and 476 days after herbicide application. Current year's growth of little bluestem, sand dropseed, red lovegrass, and purple threeawn was separated for analyses. Random samples of all herbage were subsampled after drying at $55^{\circ} \mathrm{C}$ before grinding in a Wiley mill to pass through a $0.8-\mathrm{mm}$ screen.

To determine water content, 10 randomly selected plants of little bluestem were clipped at a $1 \mathrm{~cm}$ height, weighed in the field, and transported to a dryer. When dry, the water content was calculated.

\section{Chemical and Statistical Analyses}

Duplicate 0.5-g aliquots of each sampled species were analyzed for $\mathbf{N}$ using the micro-Kjeldahl method as described by Harris (1970). Phosphorus was determined by the molybdovanado phosphate method (A.O.A.C. 1970). CWC was analyzed by the neutraldetergent procedure outlined by Goering and van Soest (1970). IVDMD was determined by the modified rumen inoculum process of the Tilley-Terry two-stage technique as used by McCawley (1978).

Nutritional parameters were analyzed using a split-plot multivariate analysis of variance (MANOVA). This test was used because, first, all plant nutritional variables have differing degrees of correlation; second, we wanted to describe and interrelate all the nutritional variables simultaneously. Description of these statistics is in a review by Harris (1975).

Factors in the analyses were: sampling date, year and treatment. Our test statistic was the great characteristic root (gcr) at the .05 level. When a ger was found significant, a mean separation test was performed using an extension of the Scheffe Test for multivariate cases (Harris 1975).

\section{Results and Discussion}

In 1978 tebuthiuron improved the quality of the species sampled. Statistical tests for treatment effect on CP, P, CWC, and 24-hr IVDMD were significant. The species-herbicide and year-herbicide interactions were significant at the 0.05 level; thus these were analyzed before conclusions could be made on herbicide main effect. 


\section{Species-Herbicide Interaction}

Treatment mean separation of the $\mathbf{4}$ dependent variables, when grouped, showed no difference between treatments for little bluestem (Table 1). Eigen vectors associated with the ger (importance of relationship) showed the most important variable studied to be $P$. Of lesser importance was $24 \mathrm{hr}-\mathrm{IVDMD}, \mathrm{CP}$, and CWC.

Table 1. Averaged nutritive content of four important grasses harvested from sandy soils in west Texas as affected by tebuthiuron.

\begin{tabular}{|c|c|c|c|c|c|}
\hline $\begin{array}{l}\text { Tebuthiuron } \\
\text { Rate (kg/ha) }\end{array}$ & $\begin{array}{l}\text { Crude } \\
\text { Protein }\end{array}$ & Phosphorus & $\begin{array}{l}\text { Cell Wall } \\
\text { Content }\end{array}$ & $\begin{array}{l}24-\mathrm{Hr} \\
\text { IVDMD }\end{array}$ & $\begin{array}{c}\text { Mean } \\
\text { Separation' }\end{array}$ \\
\hline & & & ittle Bluest & $m$ & \\
\hline $\begin{array}{l}0.0 \\
0.2 \\
0.4 \\
0.6 \\
0.8 \\
1.0\end{array}$ & $\begin{array}{l}6.3 \\
7.3 \\
7.1 \\
6.6 \\
7.3 \\
7.5\end{array}$ & $\begin{array}{l}.08 \\
.09 \\
.09 \\
.08 \\
.09 \\
.10\end{array}$ & $\begin{array}{l}71.2 \\
69.3 \\
70.3 \\
70.6 \\
68.5 \\
69.8\end{array}$ & $\begin{array}{l}22 \\
21 \\
25 \\
26 \\
26 \\
28\end{array}$ & $\begin{array}{l}\mathbf{a} \\
\mathbf{a} \\
\mathbf{a} \\
\mathbf{a} \\
\mathbf{a} \\
\mathbf{a}\end{array}$ \\
\hline 1.0 & \multicolumn{5}{|c|}{ Purple Threeawn } \\
\hline $\begin{array}{l}0.0 \\
0.2 \\
0.4 \\
0.6 \\
0.8 \\
1.0\end{array}$ & $\begin{array}{l}6.3 \\
7.5 \\
7.2 \\
7.5 \\
7.7 \\
7.7\end{array}$ & $\begin{array}{l}.08 \\
.09 \\
.08 \\
.08 \\
.09 \\
.09\end{array}$ & $\begin{array}{l}75.0 \\
74.6 \\
74.9 \\
72.0 \\
71.8 \\
72.5\end{array}$ & $\begin{array}{l}25 \\
23 \\
26 \\
27 \\
28 \\
32\end{array}$ & $\begin{array}{l}\text { a } \\
\mathbf{a} \\
\mathbf{a} \\
\mathrm{a} \\
\mathrm{b} \\
\mathrm{b}\end{array}$ \\
\hline 1.0 & \multicolumn{5}{|c|}{ Red Lovegrass } \\
\hline $\begin{array}{l}0.0 \\
0.2 \\
0.4 \\
0.6 \\
0.8 \\
1.0\end{array}$ & $\begin{array}{l}7.1 \\
8.2 \\
8.2 \\
8.7 \\
9.1 \\
9.1\end{array}$ & $\begin{array}{l}.08 \\
.09 \\
.09 \\
.10 \\
.11 \\
.10\end{array}$ & $\begin{array}{l}67.7 \\
67.2 \\
68.0 \\
69.3 \\
68.2 \\
68.5\end{array}$ & $\begin{array}{l}25 \\
25 \\
26 \\
29 \\
28 \\
31\end{array}$ & $\begin{array}{l}a \\
a \\
a \\
b \\
b \\
b\end{array}$ \\
\hline 1.0 & \multicolumn{5}{|c|}{ Sand Dropseed } \\
\hline $\begin{array}{l}0.0 \\
0.2 \\
0.4 \\
0.6 \\
0.8 \\
1.0\end{array}$ & $\begin{array}{r}8.6 \\
9.1 \\
9.2 \\
9.5 \\
9.7 \\
10.0\end{array}$ & $\begin{array}{l}.11 \\
.12 \\
.11 \\
.12 \\
.12 \\
.12\end{array}$ & $\begin{array}{l}72.4 \\
70.7 \\
72.6 \\
71.8 \\
70.8 \\
71.5\end{array}$ & $\begin{array}{l}31 \\
30 \\
32 \\
32 \\
33 \\
35\end{array}$ & $\begin{array}{l}\mathbf{a} \\
\mathbf{a} \\
\mathbf{a} \\
\mathbf{a} \\
\mathbf{a} \\
\mathbf{a}\end{array}$ \\
\hline
\end{tabular}

'Treatments within species followed by the same letters are not different at the $5 \%$ level (Scheffe contrast method for multi-variate analysis).

Nutritive value of purple threeawn was similar at the 0.8 and 1.0 $\mathrm{kg} / \mathrm{ha}$ rates. As herbicide rate increased, quality improved, but no difference was found at rates of $0.6 \mathrm{~kg} / \mathrm{ha}$ or lower. Eigen vector values indicated $P$ and $24 \mathrm{hr}-$ IVDMD to be the primary parameters causing these differences.

Red lovegrass quality was improved at rates over $0.4 \mathrm{~kg} / \mathrm{ha}$. The $C P$ was of greater importance in affecting quality than was $P$. The $24 \mathrm{hr}$-IVDMD was second in importance while CWC was of least importance. Averaged over sampling dates, $\mathrm{CP}$ in lovegrass was up to $28 \%$ higher in treated than untreated plants.

Sand dropseed quality was not affected by tebuthiuron rates; however, there was a trend towards slightly higher quality.

Specific modes of tebuthiuron activity in these grasses are not known. Two hypotheses in regards to protein synthesis and $\mathbf{N}$ uptake have been suggested: one emphasized alterations in the DNA-RNA complex (Moreland et al. 1969, Malhotra and Hanson 1970); the other suggested modifications in the carbohydrateprotein enzyme system (Tweedy and Ries 1967, Wu et al. 1971). Generally plants most susceptible to herbicide damage show the highest increase in $\mathrm{N}$. In this research little bluestem at the $1.0 \mathrm{~kg}$ rate only had temporary chlorotic effects in 1978; other grasses did not.

\section{Year-Herbicide Interaction}

In 1978 quality parameters were increased by herbicide treatment (Table 2). Grasses treated at the 0.8 and $1.0 \mathrm{~kg} /$ ha rates were higher in quality than untreated grasses. At 0.4 and $0.6 \mathrm{~kg} / \mathrm{ha}$ of tebuthiuron, quality was lower but significantly higher than in 0.2

Table 2. A veraged nutritive value of four dominant grasses on sandy soils in west Texas after treatment with tebuthiuron.

\begin{tabular}{|c|c|c|c|c|c|c|}
\hline Year & $\begin{array}{l}\text { Tebuthiuron } \\
\text { Rate (kg/ha) }\end{array}$ & $\begin{array}{l}\text { Crude } \\
\text { Protein }\end{array}$ & $\begin{array}{l}\text { Phos- } \\
\text { phorus }\end{array}$ & $\begin{array}{c}\text { Cell Wall } \\
\text { Content }\end{array}$ & $\begin{array}{c}\text { 24-Hr } \\
\text { IVDMD }\end{array}$ & $\begin{array}{c}\text { Mean } \\
\text { Separation }\end{array}$ \\
\hline 1978 & $\begin{array}{l}0.0 \\
0.2 \\
0.4 \\
0.6 \\
0.8 \\
1.0\end{array}$ & $\begin{array}{r}7.2 \\
8.3 \\
8.2 \\
8.3 \\
8.9 \\
10.0\end{array}$ & $\begin{array}{l}.09 \\
.10 \\
.10 \\
.10 \\
.11 \\
.12\end{array}$ & $\begin{array}{l}72.0 \\
70.6 \\
71.6 \\
71.3 \\
70.6 \\
70.9\end{array}$ & $\begin{array}{l}27 \\
25 \\
28 \\
29 \\
28 \\
32\end{array}$ & $\begin{array}{l}a^{1} \\
a \\
b \\
b \\
c \\
c\end{array}$ \\
\hline 1979 & $\begin{array}{l}0.0 \\
0.2 \\
0.4 \\
0.6 \\
0.8 \\
1.0\end{array}$ & $\begin{array}{l}6.9 \\
7.9 \\
7.6 \\
7.9 \\
8.0 \\
8.1\end{array}$ & $\begin{array}{l}.08 \\
.09 \\
.09 \\
.09 \\
.09 \\
.09\end{array}$ & $\begin{array}{l}71.0 \\
70.3 \\
71.3 \\
70.6 \\
69.2 \\
70.0\end{array}$ & $\begin{array}{l}25 \\
26 \\
27 \\
29 \\
29 \\
31\end{array}$ & $\begin{array}{l}\mathbf{a} \\
\mathbf{a} \\
\mathbf{a} \\
\mathbf{a} \\
\mathbf{a} \\
\mathbf{a}\end{array}$ \\
\hline
\end{tabular}

'Treatments within years followed by the same letters are not different at the $5 \%$ level (Scheffe contrast method for multivariate analysis).

$\mathrm{kg} / \mathrm{ha}$ and untreated grasses. The primary component contributing to these differences was P followed by CP, CWC, and 24 hr-IVDMD. No statistical difference was found in quality parameters between treatments in 1979.

Sandy soils of this community are inherently low in fertility; especially $\mathbf{N}$ and $\mathbf{P}$. Soil water available for plant growth is typically adequate early in the growing season. A study, in progress, suggests that soil $\mathrm{N}$ does not significantly increase the first and second year after tebuthiuron application, thus new sources of $P$ and $\mathbf{N}$ are not available. Potentially the grasses have a "mining effect" on nutrients formerly used by oak. If this was the case, all forages in treatments with near total kill, $0.6 \mathrm{~kg} / \mathrm{ha}$ or more, should have similar quality parameters.

Forty days after tebuthiuron was applied, herbage $\mathbf{C P}$ and $\mathbf{P}$ were significantly increased (Fig. 1). Throughout 1978 and in May 1979 , CP was still higher in treated grasses. By 412 days after treatment, no difference was found in these 2 parameters. Phosphorus levels in the grasses sampled declined as maturity was reached by the August sampling date.

Although there was no difference in $\mathrm{CP}$ and $\mathrm{P}$ contents of the grasses 14 months after treatment with tebuthiuron, yield of grasses increased dramatically. When peak biomass was reached in July 1979, 3 to 5 times more grass herbage was present in the tebuthiuron-treated than untreated plots. Consequently, the total nitrogen removed from the soil was much higher in the treated plots.

\section{Herbicide Main Effect}

When rate was analyzed, tebuthiuron improved herbage quality. The $1.0-\mathrm{kg} / \mathrm{ha}$ rate produced the highest quality forages in this study. The $\mathrm{CP}$ of grasses from the $0.0,0.2,0.4,0.6,0.8$, and 1.0 $\mathrm{kg} /$ ha rates was $7.1,8.0,7.9,8.1,8.5$, and 8.6 , respectively. Forage digestibility varied from 26 to $32 \%$ in the untreated and $1.0-\mathrm{kg}$ treatment. Similarly, P levels increased from 0.09 to $0.11 \%$ in these treatments.

Although the cause of a forage quality enhancement after tebuthiuron treatment is not known, the influence is positive. We assume that complex herbage, environment, and herbicide interactions occur after tebuthiuron application. Because physiological mechanisms were not studied in this research, caution should be exercised before extrapolating to other areas.

\section{Bluestem Water Content}

Little bluestem was the most abundant grass in the research area. 


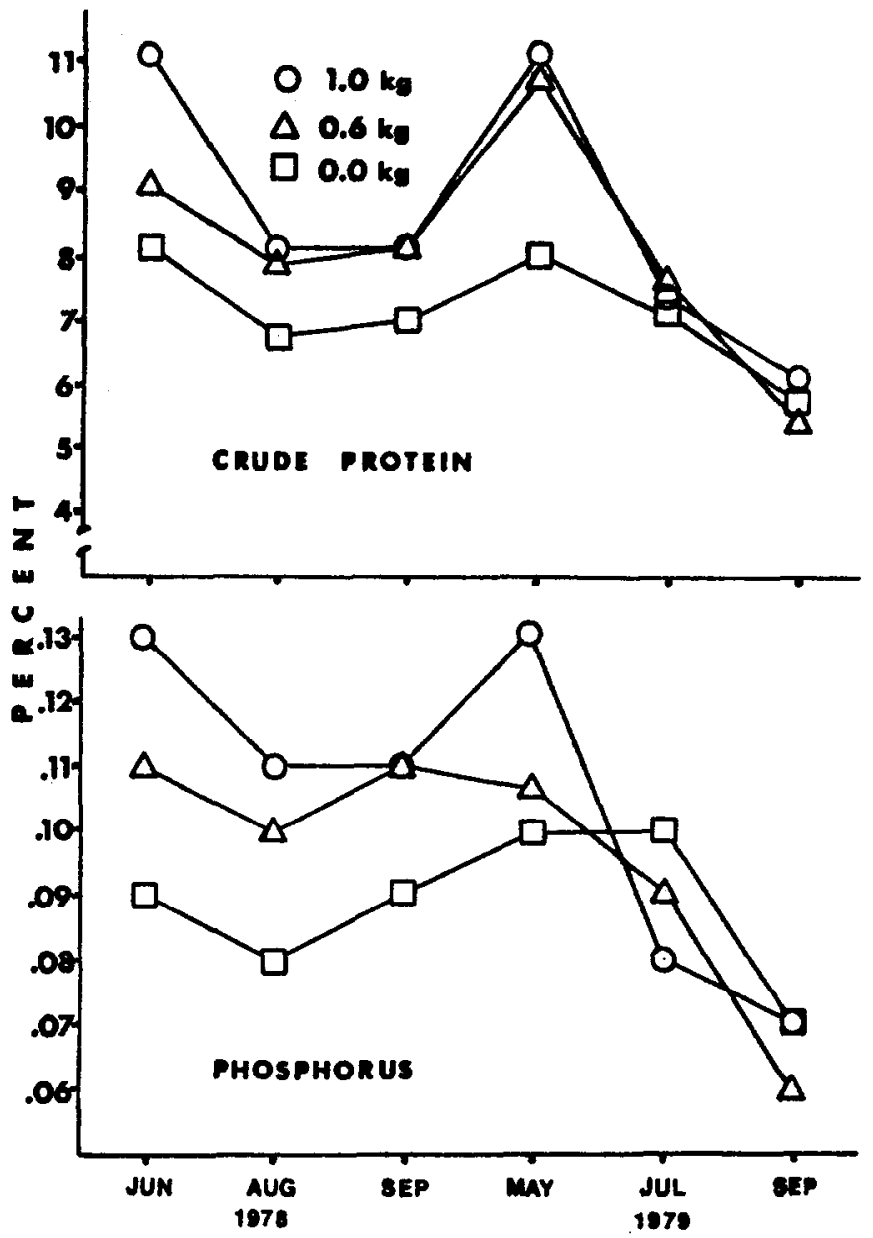

Fig. 1. Average crude protein and phosphorus percentages of current year's growth of 4 dominant grasses of west Texas sandy soils as affected by 3 rates of tebuthiuron. Samples were taken $40,67,108,349,412$, and 476 days after treatment.

Water content of this grass was significantly increased in the tebuthiuron-treated plots (Fig. 2). When untreated, this grass was $28 \%$ water in June 1978 . In the $0.2-$ and $0.4-\mathrm{kg} /$ ha plots, it contained 37 and $41 \%$ water, respectively. At higher herbicide rates, over $42 \%$ of the herbage was water. In late summer all little bluestems had similar water contents.

This study was repeated in 1979 and similar results were obtained. Over all sampling dates, bluestem treated with $0.8 \mathrm{~kg} / \mathrm{ha}$ of tebuthiuron averaged $51 \%$ water. Untreated plants, for the same period, averaged $39 \%$ water. At the $0.2 \mathrm{~kg}$ rate, bluestem had $8 \%$ more water than in untreated plants.

\section{Considerations}

Tebuthiuron is being applied commercially in several states. The most evident positive benefit in our research area is the increased forage yield after oak is killed. Replacement of oak with grasses can increase stocking rates.

During the summer of 1980 the tebuthiuron-treated grasses produced growth during drought whereas no growth was observed in the untreated grasses from May to August. Grasses in treated areas began growth up to 3 weeks before those in untreated areas, consequently the green forage grazing season is extended. In treated areas we are not concerned with livestock poisoning losses.

Vegetation on these soils produces highly palatable grazing after oak is controlled. Quality of forage is a major concern in treated and untreated areas. Although this study analyzed the entire green plant, it is doubtful if an animal can selectively graze leaf material or enough forbs to meet their $P$ requirement. Ranchers who do not
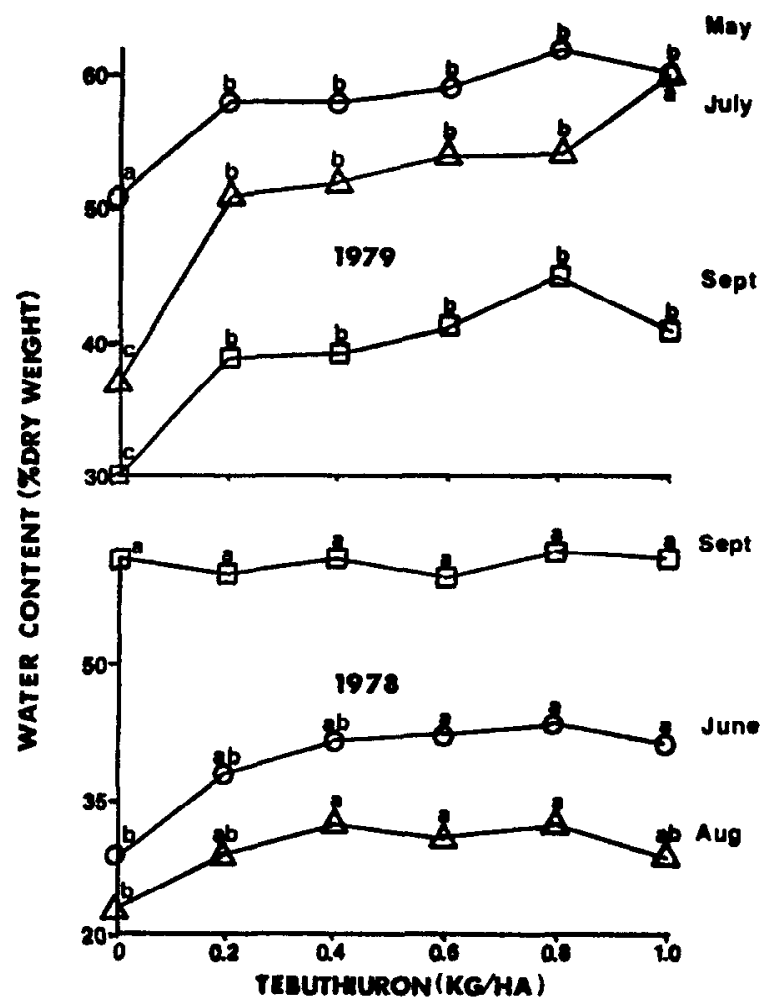

Fiz. 2. Average water content of little bluestem herbage as affected by tebuthiuron treatments. Sampling dates within years correspond to early vegetative, flowering, and ripe seed stages of development. Means within a sample date followed by the same letter do not differ at the 0.05 level.

supply a good mineral mix typically get "creepy" cattle and a reduced calf crop.

More research is needed to study the mechanisms or reasons why herbage quality parameters increase in treated areas. Second, we need explanations for the dramatic increase in grass yields post treatment. We do not believe it is entirely related to released competition.

\section{Literature Cited}

Arnold, G.W. 1964. Factors within plant associations affecting the behaviour and performance of grazing animals. p. 133-154. In: D.J. Drisp (ed.). Grazing in Terrestrial and Marine Environments. Blackwell Sci. Pub. Oxford.

Bovey, R.W., R.E. Meyer, and H.L. Morton. 1972. Herbage production following brush control with herbicides in Texas. J. Range Manage. 25:136-142.

Currey, W.L. 1972. Influence of simazine on crude protein production and cell wall constitutents of alfalfa (Medicago sativa L.) and orchardgrass (Dactylis glomerata L.). Diss. Abstr. Int. 33:2428-2429.

Goering, H.K., and P.J. Van Soest. 1970. Forage fiber analysis. Agr. Res. Serv., USDA Handb. 379.

Harris, L.E. 1970. Nutrition research techniques for domestic and wild animals. Utah State Univ., Logan.

Harris, R.J.1975. A primer of multivariate statistics. Academic Press, New York.

Houston, W.R., and D.H. van Sluijs. 1975. Increasing crude protein content of forage with atrazine on shortgrass range. Agr. Res. Serv., USDA Prod. Res. Rep. 153.

Leigh, J.H. 1961. The relative palatability of various varieties of weeping lovegrass (Eragrostis curvula). J. Brit. Grassl. Soc. 16:135-140.

Malhotra, S.S., and J.B. Hanson. 1970. Picloram sensitivity and nucleic acids in plants. Weed Sci. 18:1-3.

McCawley, P.F. 1978. An evaluation of three exotic grasses for pasture in the Coastal Bend. M.S. Thesis. Texas Tech Univ., Lubbock. 
Moreland, D.E., S.S. Malhotra, R.D. Gruenhazer, and E.H. Shokrail. Sosebee, R.E. 1979. Influence of tebuthiuron on forage quality of selected 1969. Effects of herbicides on RNA and protein syntheses. Weed Sci. 17:556-562.

Pettit, R.D. 1979. Effects of picloram and tebuthiuron pellets on sand shinnery oak communities. J. Range Manage. 32:196-200.

Sclfres, C.J., G.R. Durham, and J.L. Mutz. 1977. Range forage production and consumption following aerial spraying of mixed brush. Weed Sci. 25:45-54. grasses-preliminary evaluations. Southern Weed Sci. Soc. Proc. 32:334346.

Tweedy, J.A., and S.K. Ries. 1967. Effects of simazine on nitrate reductase activity in corn. Plant Physiol. 42:280-282.

Wu, M.T., B. Singh, and D.K. Salunkhe. 1971. Influence of S-triazine on some enzymes of carbohydrate and nitrogen metabolism in leaves of pea (Pisum sativum L.) and sweet corn (Zea mays L.). Plant Physiol. 48:517-520. 